УДК 656.254.5

\title{
УДОСКОНАЛЕННЯ ДИСПЕТЧЕРСЬКОГО УПРАВЛІННЯ НА ДІЛЬНИЦІ В УМОВАХ ШВИДКІСНОГО РУХУ
}

\author{
Канд. техн. наук П.В. Долгополов, магістрант Р.В. Чікаров \\ СОВЕРШЕНСТВОВАНИЕ ДИСПЕТЧЕРСКОГО УПРАВЛЕНИЯ НА УЧАСТКЕ В \\ УСЛОВИЯХ СКОРОСТНОГО ДВИЖЕНИЯ
}

\section{Канд. техн. наук П.В. Долгополов, магистрант Р.В. Чикаров \\ IMPROVEMENT OF THE DISPATCH CONTROL AT THE RAILWAY DISTRICT IN CONDITIONS OF HIGH SPEED MOVEMENT}

\author{
Cand. of techn. sciences P.V.Dolgopolov, master student R.V. Chikarov
}

Для розвитку високошвидкісного руху на залізнииях розроблено заходи з розширення складу функиіональних задач диспетчерських систем управління. Запропонована модель розрахунку прогнозного графіка руху поӥзів з урахуванням оперативних змін у перевізному прочесі, яка дає змогу ефективно адаптувати вантажну роботу на дільниці під розклади високошвидкісних поїздів.

Ключові слова: диспетчерське управління, прогнозний графік руху поїдів, безпека руху, обмеження швидкості, високошвидкісний рух.

Для развития высокоскоростного движения на железных дорогах разработаны меры по расширению состава функциональных задач диспетчерских систем управления. Предложена модель расчёта прогнозного графика движения поездов с учётом оперативных изменений в перевозочном прочессе, позволяющая эффективно адаптировать грузовую работу на участке под расписание высокоскоростных поездов.

Ключевые слова: диспетчерское управление, прогнозный график движения поездов, безопасность движения, ограничение скорости, высокоскоростное движение.

For the development high-speed railways developed measures to expand the composition of the functional tasks of dispatching control systems. A model of the calculation the forecast traffic schedule, considering operational changes in the transportation process, which can effectively adapt the cargo work at the railway district under the schedule high-speed trains.

Keywords: dispatching control, projected schedule of trains, traffic safety, speed limit, high speed movement.

Вступ. Велика провізна спроможність залізниць, стабільність їх роботи та порівняна дешевина перевезень сприяли тому, що залізничний транспорт був i залишається основним перевізником пасажирів та вантажів у дальньому сполученні.

Однак сьогодні залізниці вже не повною мірою відповідають сучасним вимогам, які висуваються до транспорту, насамперед щодо тривалості поїздок. Радикальним заходом, який дасть залізницям змогу зберегти передові позиції у сфері пасажирських перевезень, $\epsilon$ створення мережі високошвидкісних магістралей (ВШМ), що забезпечить значне зростання обсягів залізничних перевезень, у тому числі за рахунок залучення пасажирів 3 інших видів транспорту.

ВШМ дають змогу підвищити мобільність пасажирів, а також формують нові мультимодальні транспортні системи спільно 3 авіасполученням, приміськими поїздами i громадським міським транспортом. ВШМ займають чітко виражену нішу в діапазоні відстаней 200-700 км, де високошвидкісні поїзди (зі швидкістю понад 200 км/год) забезпечують більш високий рівень комфорту $\mathrm{i}$ безпеки, ніж автомобільні i повітряні транспортні засоби [1].

Постановка задачі дослідження. Метою цієї роботи $є$ побудова системи диспет- 
черського управління, яка дасть змогу створити максимальні умови для оптимізації маршрутів прямування та безперервного контролю за безпекою руху поїздів 3 боку оперативнодиспетчерського персоналу.

Основна частина дослідження. Для реалізації безпечного та ефективного руху на дільницях в умовах високошвидкісного руху при дослідженні проаналізовано існуючі та перспективні мікропроцесорні системи диспетчерської централізації (МСДЦ), зокрема «Сетунь», «Каскад», «Дон», «Тракт», «Діалог» та ін.

Застосування цих МСДЦ на залізницях дає змогу:

- автоматизувати та максимально спростити операції з управління рухом поїздів;

- оперативно надавати якісну інформацію про поїзний стан та стан пристроїв котролю;

- зменшити вплив суб'єктивного фактора при прийнятті рішень та підвищити рівень безпеки руху тощо.

Кожна система має свої переваги та недоліки, проте, як показали дослідження уваги, перш за все заслуговує МСДЦ «Каскад» за рахунок таких іiї інтелектуальних функцій:

- телеуправління пристроями автоматики з автоматизованого робочого місця поїзного диспетчера (ДНЦ) 3 можливістю постановки маршрутів у чергу;

- автоматизована побудова графіків виконаного та прогнозного рухів поїздів 3 відображенням плану поїзної роботи на дільниці;

- прогнозне управління рухом поїздів,що формує маршрути поїздам по прогнозних нитках графіка руху поїздів (ГРП).

Проте реалізації всіх цих функцій перешкоджають такі його недоліки,які необхідно усунути під час дослідження:

- у МСДЦ «Каскад» не відображаються попередження в місцях зменшення швидкості;

- побудова прогнозного графіка руху поїздів здійснюється тільки за нормативними елементами ГРП, не враховуючи такі тимчасові фактори перевізного процесу, як наявність попередження, наявність пасажирських платформ та ін.;

- МСДЦ «Каскад» не відображає з'єднання поїздів на дільниці, що перешкоджає введенню модульного руху поїздів [2].
Для того, щоб створити максимальні умови для оптимізації маршрутів прямування та безперервного контролю за безпекою руху поїздів, необхідно усунути недоліки МСДЦ «Каскад».

Для досягнення мети потрібно враховувати нижченаведені вимоги. При попутному русі відстань між сусідніми поїздами (міжпоїзний інтервал) безперервно змінюється. Так, при підході першого поїзда якої-небудь пари сусідніх поїздів до станційної платформи, де він повинен зупинитися, його швидкість знижується, другий поїзд починає наздоганяти його i, як наслідок, відстань між поїздами скорочується. Аналогічна ситуація наявна і при позапланових змінах швидкостей поїздів через відмови елементів колії, рухомого складу та інших технічних засобів. Міжпоїзні відстані змінюються також тому, що поїзди переміщаються дуже часто по ділянках 3 різними планами $\mathrm{i}$ профілями. Разом 3 тим у всіх випадках вони повинні бути достатніми для запобігання зіткнень поїздів,особливо це актуально в умовах високошвидкісного руху $[3,4]$.

Коли перший поїзд знижує швидкість до нуля внаслідок необхідності зупинки, а другий змушений знижувати швидкість для виключення зіткнення 3 ним, при цьому припускається, що гальмівний шлях другого поїзда $\mathrm{S}_{2}$ більше гальмівного шляху першого $S_{l}$. Другий поїзд встигне знизити швидкість і його локомотив зупиниться перед хвостовим вагоном першого тільки у випадку, якщо в момент початку гальмування першого поїзда відстань Lхг між його хвостовим вагоном i локомотивом другого поїзда буде не менше різниці гальмівних шляхів поїздів $S_{1}, S_{2}$. Отже, для виключення зіткнення двох сусідніх попутних поїздів система управління рухом повинна забезпечити виконання умови

$$
L_{\mathrm{X} \Gamma}>S_{T 1}-S_{T 2 .} .
$$

При цьому $L_{\mathrm{Xг}}$ розраховується як

$$
L_{\mathrm{X} \Gamma}=x_{x 1}-\mathrm{x}_{x 2} \text {, }
$$

де $x_{x 1}$ - координата хвостового вагона першого поїзда;

$x_{x z}$-координата локомотива другого поїзда. 


\section{Експлуатація залізниць}

Забезпечення нерівності (1) $є$ першою найважливішою задачею управління рухом поїздів.

Відстань між поїздами прийнято визначати не через координати хвоста першого поїзда і голови другого, а через координати середин поїздів:

$$
L=x_{1}-x_{2}=\left(x_{x 1}+0.5 l_{\Pi 1}\right)-\left(x_{x 2}-0.5 l_{\Pi 2}\right) \text {. }
$$

Через те, що завжди $є$ похибки вимірювань координат поїздів, довжин їх складів i розрахунків гальмівних шляхів, мінімальна за умовами безпеки руху відстань між поїздами, яку прийнято називати розрахунковою, визначається за формулою

$$
L_{\mathrm{P}}=S_{2}-S_{1}+0.5\left(l_{\Pi 1}+l_{\Pi 2}+\Delta l_{\Pi 1}+\Delta l_{\Pi 2}\right)+\sum_{i=1} \Delta l_{\Pi i},
$$

де $L_{\mathrm{P}}$ - розрахункова відстань між поїздами,м;

$l_{\Pi 1}, l_{\Pi 2}$ - довжина поїздів,м;

$\Delta l_{\Pi 1}, \Delta l_{\Pi 2}$ - похибки визначень довжин составів,м.

Таким чином, завдання запобігання зіткненню попутних поїздів зводиться до завдання забезпечення рівняння

$$
L>L_{p} .
$$

На рис. 1 показано рух поїзда при наявності обмеження швидкості до величини $V_{O Г}$. Величина $V_{O Г}$ встановлюється такою, щоб запобігти сходженню рухомого складу поїзда 3 рейкової колії при русі по цій ділянці.
Наприклад, швидкість руху по ділянці може бути обмежена через погіршення параметрів залізничної колії.

Система управління рухом повинна забезпечити фактичну швидкість входу локомотива на ділянку, фактичну швидкість руху поїзда по ділянці і фактичну швидкість виходу хвостового вагона поїзда 3 ділянки $V_{\Phi}$ не вище $V_{О Г \text {. }}$

$$
t_{\mathrm{X}}^{\mathrm{AE}}=t_{\text {до }}+t_{\mathrm{y}}+t_{\text {огр }}+t_{\mathrm{p}}+t_{\text {посл }},
$$

де $t_{\mathrm{y}}$ - час на гальмування поїзда;

$t_{\mathrm{p}}$ - час на розгін.

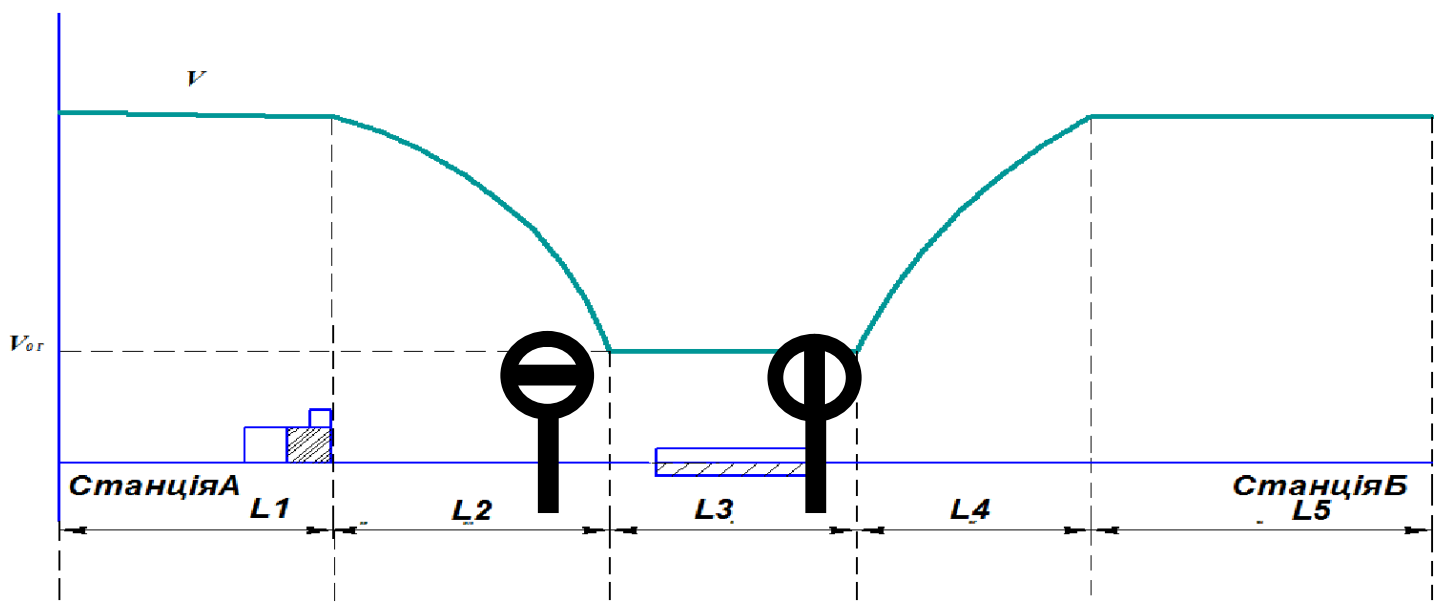

Рис. 1. Графік руху поїзда при русі по ділянці з обмеженою швидкістю

При цьому $t_{\text {до }}, t_{\text {посл }}$ розраховується як

$$
\begin{aligned}
& t_{\text {до }}=\frac{L_{\text {до }}}{V_{\text {до }}}, \\
& t_{\text {послл }}=\frac{L_{\text {посл }}}{V_{\text {посл }}} .
\end{aligned}
$$

У свою чергу $t_{\mathrm{y}}, t_{\mathrm{p}}$ визначено як

$$
\begin{gathered}
t_{\mathrm{y}}=2 p L, p>0, \\
t_{\mathrm{p}}=2 p L, p>0 .
\end{gathered}
$$




\section{Експлуатація залізниць}

Тоді як $t_{\text {огр }}$ розраховується як

$$
t_{\text {огр }}=\frac{L_{\text {огр }}+L_{\text {пा }}}{V_{\text {огр }}} .
$$

Таким чином, другим завданням управління рухом поїзда $\epsilon$ забезпечення виконання умови

$$
V<V_{\text {ОГ }} \text {. }
$$

Для виключення зіткнення поїзда 3 транспортним засобом іншого виду на переїзді система управління повинна своєчасно сформувати команду пристроям, які огороджують переїзд, на заняття положень, при яких був би виключений в'їзд транспортного засобу на залізничний переїзд перед самим поїздом. Це $\epsilon$ третім завданням системи управління.

Таким чином, завданнями забезпечення безпеки при управлінні рухом поїздів $\epsilon$ запобігання:

- зближенню поїздів на відстань менше допустимого за умовами безпеки руху (запобіганню зіткнення поїздів);

- руху поїздів зі швидкостями вище допустимих за умовами безпеки (запобігання сходу поїзда);

- заняття залізничного переїзду транспортним засобом будь-якого виду, якщо воно не зможе його звільнити до входу на переїзд поїзда.

Успішність вирішення цих завдань залежить від функціональних властивостей i технічних параметрів систем керування рухом.

Також необхідно максимально підвищити дільничну швидкість. Для цього дільнична швидкість може бути розрахована за формулою

$$
V_{y}=\frac{\Sigma_{i} l_{i}}{\Sigma_{l} t_{l}+\Sigma_{J} t_{i}^{p 3}+\sum_{k} t_{c k}},
$$

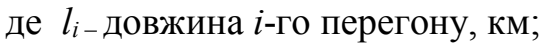

$t_{i}$ - час ходу поїзда по $i$-му перегону, год;

$t_{j}^{\mathrm{p} 3}-$ час $j$-го розгону та сповільнення, год;

$t_{c k}-$ середній час $k$-ї стоянки, год.

Підвищення дільничної швидкості завжди актуальне, тому що сприяє зниженню собівартості перевезень. Тому потрібно завжди прагнути так управляти рухом, щоб дільнична швидкість була максимальною.

3 (11) випливає, що $V_{y}$ поїзда збільшується в міру зменшення його часу ходу $t_{i}$ по кожному $i$-му перегону ділянки $[5,6]$.

Розраховані в залежності від різних швидкостей руху прогнозні нитки ГРП запропоновано відображати у вигляді інтерфейсу ГРП на АРМ ДНЦ, як показано на рис. 2.

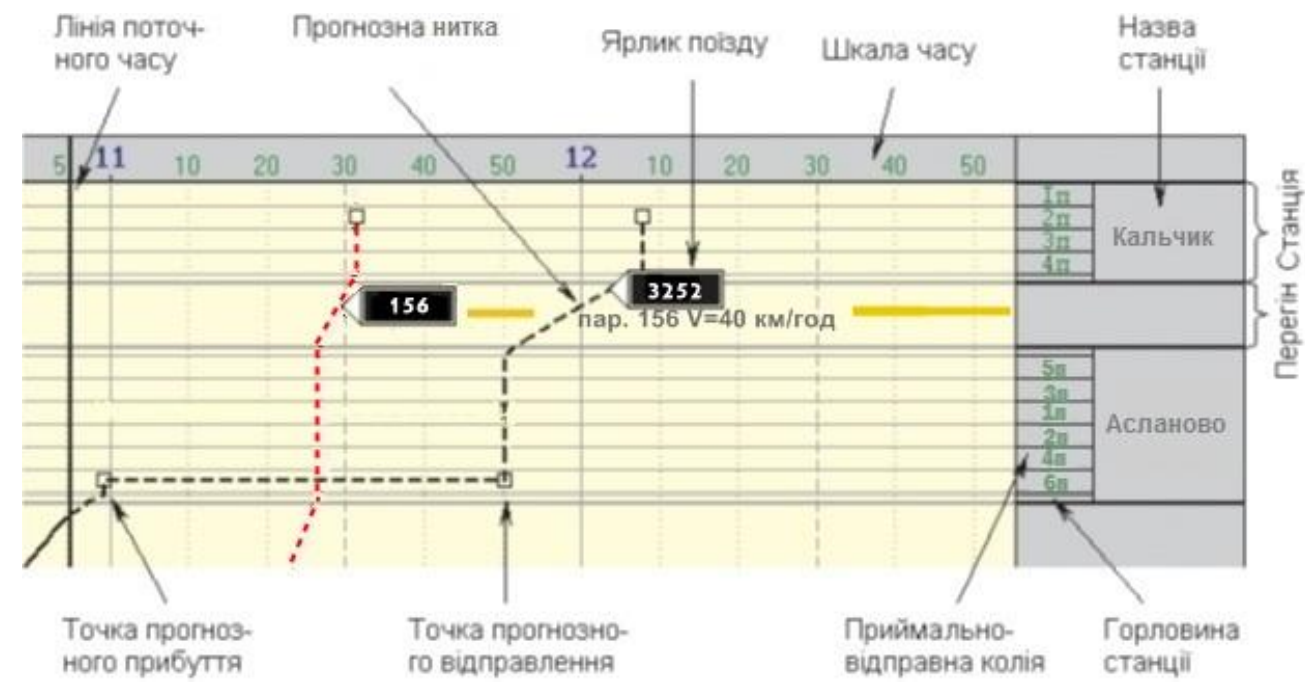

Рис. 2. Приклад інтерфейсу виконаного ГРП на АРМ ДНЦ 
На прогнозному ГРП нитка поїзда 3252 розрахована 3 урахуванням обмеження швидкості у період дії попередження.

Висновки. Розширення складу функціональних задач МСДЦ «Каскад» дає змогу складати прогнозний графік руху поїздів, враховуючи оперативні зміни в перевізному процесі. 3 урахуванням запропонованих заходів в умовах високошвидкісного руху на дільниці МСДЦ «Каскад» розраховує та пропонує поїзному диспетчеру план поїзної роботи 3 урахуванням діючих попереджень та інших обмежень швидкості на дільницях.

\section{Список використаних джерел}

1. Концепція Державної цільової програми впровадження на залізницях швидкісного руху пасажирських поїздів на 2005-2015 роки [Електронний ресурс]: розпорядження Кабінету Міністрів України від 31 грудня 2004 р. № 979-p. - Режим доступу: http://zakon2.rada.gov.ua/laws/show/9792004-p.

2. Данько, М.І. Мікропроцесорна диспетчерська централізація "КАСКАД” [Текст]: навч. посібник / М.І. Данько, В.І. Мойсеєнко, В.3. Рахматов [та ін.]. - Харків, 2005. - 176 с.

3. Манзуля, В.П. Удосконалення перевізного процессу на транспортному полігоні на основі моделі диспетчерського управління [Текст] / В.П. Манзуля, А.О. Роженко, П.В. Долгополов // Зб. наук. праць УкрДАЗТ. - Харків, 2014. - Вип. 145. - С. 11-17.

4. Системы управления движением поездов на перегонах [Текст]: учеб. для вузов ж.-д. транспорта: в 3 ч. / В.М. Лисенков. П.Ф. Бсстемьянов, В.Б .Леушин [и др.]. - М.: ГОУ «Учебнометодический центр по образованию на железнодорожном транспорте», 2009.

5. Інструкція зі складання графіка руху поїздів на залізницях України [Текст]: ЦТ-0040. - К., 2002. $-159 \mathrm{c}$.

6. Інструкція з ведення графіка виконаного руху поїздів на залізницях і дирекціях залізничних перевезень [Текст]: ЦТ-0076. - К., 2009. - 45 с.

Рецензент д-р техн. наук, професор О.М. Огар

\footnotetext{
Долгополов Петро Віталійович, канд. техн. наук, доцент кафедри управління експлуатаційною роботою Українського державного університету залізничного транспорту. Тел. 730-10-88. e-mail: pit2013@mail.ru. Чікаров Ростислав В’ячеславович, магістр ІППК. Тел.(095) 533-90-60 e-mail: rosst1992@mail.ru.
}

Dolgopolov Peter, PhD. Of tehn. Sciences, Associate Professor of Management of operational work of the Ukrainian State University of Railway Transport. Tel.730-10-88. e-mail: pit2013@mail.ru.

Chikarov Rostyslav, Lichistener IPPK. Tel. (095) 533-90-60 e-mail: rosst1992@mail.ru.

Наукова праця здана до друку 22.06.2015 року. 